\title{
Patents and Public Health in France \\ Pharmaceutical Patent Law in-the-making at the Patent Office between the two World Wars
}

\section{Maurice Cassier, CNRS}

\begin{abstract}
France excluded the patentability of pharmaceutical products for a long time, from 1844 to 1960. Yet, even though there was no change in the legal norm relative to drug patents, during the interwar period the national patent office (INPI) examined applications for pharmaceutical patents and issued a growing number of process patents on an increasingly broad range of health products. This article analyses the making of patent law by the Comité Technique de la Propriété Industrielle, comprised of jurists, patent engineers, industrialists, and professors in pharmacy. The committee produced its own corpus of rules for examining patent applications, which superceded the law. This committee's work led to two significant developments: a growth in the number of pharmaceutical process patents between 1920 and 1939, and the inclusion of biological product preparations (hormones, vaccines, vaccines, serums) into the patent sphere.
\end{abstract}

The French patent law of 1844 excluded drugs from patentability until 1960, primarily for two public health reasons. The first concerned the fight against charlatanism, to ensure that patents were not used for purely commercial purposes; the second concerned the prevention of monopolies in the medical field - an argument related to the very foundations of industrial property law ${ }^{1}$. In both cases the particular status of health products, considered to be goods unlike any others, was crucial. Yet this exclusion of 'pharmaceutical compositions or remedies of all kinds' in the 1844 law did not extend to processes of preparation of remedies, which were patentable $^{2}$. Prior to 1914 firms applied for patents on processes for synthesizing pharmaceutical products, extracting alkaloids from plants and separating vitamins, despite an unfavourable ruling by the Conseil d'Etat. The shock of WWI and the sudden awareness of the German chemical and pharmaceutical industry's superiority ${ }^{3}$ altered the terms of the debate on the patentability of pharmaceutical inventions and, more generally, on industrial property rights 
on chemicals and pharmaceuticals ${ }^{4}$. In 1915 the Académie de Médecine, which had supported the exclusion of drug patents in 1844 , recommended the issuing of pharmaceutical process patents. The prevailing idea in debates was to move closer to the German model, presented as a better incentive for the invention of new manufacturing techniques. This meant that explicit recognition of pharmaceutical process patents would be enshrined in the law. More surprisingly, following this proposal, patents on chemical products were excluded, implying that process patents were better incentives for stimulating the development of new chemical syntheses ${ }^{5}$.

Yet the change of the norm concerning drug patents was not immediately translated into law. It first appeared in the practices of the Comité Technique de la Propriété Industrielle (CTPI) of the French national patent office (Office National de la Propriété Industrielle). This technical committee, consisting of scientists, jurists and industrialists, examined patent applications liable to transgress patent exclusions, primarily the exclusion of pharmaceutical compounds. Paradoxically, while taking care to reject patents on drugs as products, the committee's rulings during the inter-war period set up a jurisprudence in favour of pharmaceutical process patents. The number of pharmaceutical patents applied for by the industry and authorized by the CTPI increased sharply in the mid-1930s ${ }^{6}$. In 1944 French patent law was amended by decree: the patentability of pharmaceutical processes was explicitly recognized, although products were still excluded ${ }^{7}$. The law thus confirmed the norm previously set by the patent office.

In this article we analyse the actual work of producing laws, carried out by the CTPI of the French patent office. We draw on the CTPI's archives from the period between 1920, when the committee was created by the Minister of Trade, and 1939. This 20-member committee met ten times a year to examine contentious patent applications referred to it by the patent office for an opinion. The exclusions provided for by the 1844 law concerned pharmaceutical compounds, credit and financing methods, scientific principles, and inventions contrary to 'public order and 
good morals', primarily contraceptive methods during the period under consideration here. Most of the patents examined by the committee concerned pharmaceutical inventions: 500 patent applications over the entire period. We have the minutes of committee meetings as well as reports drawn up for each patent application to decide on its acceptance or refusal (506 reports consisting of 1-7 typed pages). We also have the corpus of codified rules made by the committee, for examining pharmaceutical patents and amendments to them. The number and regularity of these minutes and reports attest to the reality of the practice of examining pharmaceutical patents, despite the fact that it ran counter to the principle of no prior examination of patents introduced into French patent law in 1791. In other words, the status of exception of drugs and pharmaceutical inventions as regards patent law was twofold. The exception applied first to the regime of exclusive property of inventions: in France drug formulae were free goods that could licitly be copied. Second, it concerned the liberal principle of no prior examination of patents, in terms of which the state had to guarantee the granting of industrial property rights without consideration for the substance of the invention. Disputes over the newness or industrial application of the patent were supposed to be sorted out in court. While no trace of prior examination exists for the vast majority of patents applied for and granted in other industrial sectors, pharmaceutical patents were an exception. Opinions, reflections and, where relevant, controversies concerning them abounded. They provide us with rich material for gaining insight into the changes in invention and in the pharmaceutical industry, and for monitoring law in-the-making in the intermediary bodies between the state, the academy and industry.

\section{1- Patent Law in-the-making at the CTPI: between Science, Law and Industry}


In 1915 Ernest Fourneau, director of the therapeutic chemistry laboratory at the Pasteur Institute - which, at the time, was collaborating closely with the firm Etablissements Poulencremarked on the unfavourable character of the patentability norm: "'The Conseil d'Etat ruled that any process leading to a remedy was not patentable because it could remain the only one applicable; consequently, a process patent would be confused with a product patent. The jurisprudence was set ${ }^{8}$. The firms gave up the idea of filing patent applications: 'Mr. Poulenc 9 notes that in the pharmaceutical industry the idea prevailed for a long time that it was possible to patent neither a pharmaceutical product nor its preparation process. Since the war a new set of rules has been produced by the technical committee, in terms of which preparation processes can be patented $^{\prime 10}$. For example, in the early 1920 s the discoverers of insulin decided against applying in France for a patent on their extraction process which they had patented in Canada, the USA and the UK. In July 1923 the University of Toronto, which owned the invention, chose to entrust its exploitation to the Pasteur Institute. In North America and the UK the university managed to use its property rights to establish control over the insulin industry and to withdraw it from the constraints of the drug market ${ }^{11}$. But in October 1923 Calmette informed the University of Toronto that such control over industrial production by patents would be impossible in France: 'Dr Roux and myself have studied the conditions in which, at the Pasteur Institute, we could embark on the manufacturing of this substance. We immediately found ourselves confronted with problems which are insurmountable for us since they stem from French legislation and from the fact that the preparation of drugs, serums, vaccines and biological products intended for medical use is absolutely free in our country, where no patent can protect $i t^{\prime}{ }^{12}$. Several French firms had already started to produce insulin and the Pasteur Institute could not claim to have the monopoly or to control the industry: 'It would therefore not be possible for the Pasteur Institute to prevent these firms from carrying on with their manufacturing enterprise; nor could we request the government to provide us with 
special protection or a monopoly that violated the law' ${ }^{13}$. Based on this report, the University of Toronto gave up the idea of applying for patents, including on an extraction process that it had developed. Insulin production remained totally free in France until the end of the 1930s, to the great displeasure of the University which saw itself deprived of the only means to control the production of insulin - of a very mediocre quality, according to its representative in Europe in $1924^{14}$.

While lasting reform to the patent law failed to materialize ${ }^{15}$, the patent office examined and granted a growing number of pharmaceutical patents. The number of applications examined annually rose from $10-15$ in the early 1920 s, to $60-90$ in the late 1930 s. To be sure, this is not very high compared to the 11,000 pharmaceutical specialities authorized by the Health insurance (the Assurances Sociales) in 1938, and the 15,000-20,000 patents issued annually by the patent office at the time. Yet it does reflect a change in the patent office's patentability norms and the pharmaceutical laboratories' and their IP advisers' appropriation practices.

The place in which this change took place was the CTPI, set up in March 1920 by the Minister of Trade. This expert committee had two main functions: the first was to examine patent applications likely to contravene exclusions stipulated in the law (formerly the function of the Comité Consultatif des Arts et Manufacture, from 1820) ${ }^{16}$; the second was to reflect and debate on the evolution of industrial property legislation 'which no longer corresponds entirely to the progress of science and the needs of trade and industry' ${ }^{17}$. It participated in debate on the maintenance or cancellation of patents on chemical products.

The committee brought together competencies from the scientific and legal professions and from industry: 'It was with this aim that more space was made within the industrial property technical committee for representatives of industry, and that it was planned to appoint special technical rapporteurs who would be attached to the committee and could provide it with their particular technical knowledge every time a case was referred to $i t^{\prime 18}$. In the inter-war period 
the technical committee had between 20 and 25 members, as well as the special technical rapporteurs whose number increased in the 1930s to cope with the growing number of pharmaceutical patents. With four or five lawyers or law professors, depending on the period, it had a high level of legal competencies. In 1920 members of the committee included: Lyon Caen, secretary of the Académie des Sciences Morales et Politiques; Mainié, author of a treatise on patents that became a reference; Allart, who had published a book in 1883 on industrial property and pharmaceuticals; and Marcel Plaisant, lawyer and member of parliament who played an essential role between the wars drafting reforms to patent law ${ }^{19}$. The committee also had four or five representatives of inventors' societies and associations to promote industrial property, as well as a representative of the IP consultants' profession. In 1920 this representative was from the firm Blétry, one of the most renowned in Paris. The presence of a representative of patent engineers promoted the circulation of the committee's rulings within the profession. Academic circles were also represented by three or four members of the Académie des Sciences, the Académie de Médecine, and the Conservatoire National des Arts et Métiers. In the 1920s Gabriel Bertrand, professor at the Pasteur Institute and member of the science academy was appointed to the committee. Bertrand was a biologist involved in the promotion of industrial property, and was vice-chairman of the syndicate of French inventors. Several scientists and jurists were also members of inventors' or engineers' societies, for instance Laubeuf, member of the science academy and chairman of the civil engineering society, and Mainié, lawyer and member of the association of industrial inventors and artists. Industry was strongly represented (four or five members), especially chemicals and pharmaceuticals. Throughout that entire period the chairman of the Union des Industries Chimiques, Duchemin and then Camille Poulenc, participated in its work. Their presence was more than formal: Duchemin took part in debates on the patentability of chemical products and drew up several reports on patents in his field; Camille Poulenc participated directly in the process of examining pharmaceutical patents 
- he signed many examination reports - and establishing the committee's rules in this respect. Finally, the committee was chaired by representatives of the patent administration: the director of industrial property from the Trade Ministry attended all the meetings. This type of organization facilitated interaction and the transfer of ideas and norms between the state and industry, between science and law, and between IP doctrine and practice. The combined competencies in patent law, science and industrial technology also made it possible to elaborate patent norms which closely corresponded to technical objects (To what extent were the means of obtaining vaccines or hormones sufficiently described and defined to decide on their patentability?). The committee included many experts in chemicals and pharmaceuticals (senior members of the faculty of pharmacy, industrial pharmacists, dispensary pharmacists, professors in pharmacy).

The high level of participation on the committee of chemists and pharmacists, industrialists and scientists, as well as the appointment of 'special technical rapporteurs', clearly signified that the examination of patents was not merely a formality. The length and content of examination reports further attested to this. To refuse a patent on a drug, the rapporteurs had to examine its technical content: did the claims cover a product intended for therapeutic use, which would not qualify for a patent, or a chemical product without medical use, which was patentable? Did it concern a medicinal substance, which was not patentable, or simply a vehicle or a carrier for a remedy, which was patentable? To reach a conclusion the rapporteur had to undertake an indepth analysis of the description of the invention and the patent claims, which was far more than a formality: 'Usually the applications submitted to him for examination are presented under the heading: "process for" whereas in fact it concerns simple pharmaceutical compounds. If we referred to the title only without examining the application itself, there would certainly never be an unfavourable conclusion. The rapporteurs therefore wish to point out that in such cases they believe that their mission is to examine the description ${ }^{20}$. The jurists of the 
committee acknowledged the reality of examination of drug patents, in contravention of French patent law: 'Application of Article 3 of the 1844 law necessarily requires the Administration to perform a prior examination and Mainie notes that he reached this conclusion in his 1896 treatise on patents ${ }^{21}$. During the debate on the Mayo Clinic patent on thyroxin, a jurist recognized that 'even if the committee does not have the power to examine the novelty of the invention, one cannot deny that by law it has the right in certain cases to examine its content' 22. The rapporteurs incorporated criteria of inventive activity and industrial application into their judgements when they attempted to distinguish between 'real industrial processes' and 'mere mixtures'. They also took into account the principles of novelty and priority when they accepted patents on a pioneer invention, even if it was not perfectly defined and stabilized, in order not to penalize the first inventor to the benefit of subsequent inventors.

This process of examination involved interactions between the rapporteurs and the inventors or IP consultants representing them. When the technical committee received a patent likely to concern a remedy, the appointed rapporteur would usually question the applicant and require him to justify and to document his claim. Sometimes the applicant would supply a technical report to explicate the nature of the product and its process: 'the applicant indicated in the report that he had been asked to supply after filing the application ...' (patent application, I.G. Farben, 1929). In 1929 the inventors of a hormone preparation process, whose patent application was initially refused by the Committee, requested a meeting with the rapporteurs to defend the patentability of their process. They supplied technical documentation which reviewed the most recent scientific publications on hormones. This convinced the committee which changed its position and granted the patent. These interactions between the rapporteur and the patent applicant show the reality of the examination work which required interactions as well as data and document transfers between the two parties. 
Other tangible proof of the examination work was the fact that the committee very often requested amendments to patents (deletion of claims or even passages in the description directly concerning a pharmaceutical product or, more rarely, requests to change the title or rewrite the patent document). In 1931 a report noted that these requests to amend patents were allowed: 'At the time of the Rigollot affair ${ }^{23}$ there was no technical committee and we could not require the deletion of certain terms from the descriptive report. But now it is allowed, and rightly so' (Hense patent, 1931). Yet certain jurists on the CTPI were hostile to extensive amendments, which attested too clearly to the committee's examination: 'Even if, after the favourable work of the administration and in line with the technical committee's numerous opinions, deletions have been allowed in the descriptions submitted, it cannot be accepted that a new description be substituted for the one initially submitted with the patent application'.

An appeal procedure against the committee's decisions was even ratified in 1935. Until then the technical committee had turned down no request to re-examine a patent application initially refused, in order not to substantiate the fact that an examination had been undertaken. This changed in 1935, under pressure due to the number of patent applicants who requested a re-examination: 'Since then, the number of patent applications for which the agents have requested a new examination has multiplied and one agent have even requested a third examination of the same patent application. To date, the administration has not wanted to refuse patent applicants an appeal against the technical committee's decisions, but it fears that if these appeals are accepted too easily, the Committee's opinions will lose their force ...'. Reexaminations were consequently limited to two. This decision was a further step in the codification of the procedure for examining pharmaceutical patents.

During the period under study the committee produced a corpus of rules to statute on the acceptability or not of patents that seemed to concern remedies. These rules governing the patentability of pharmaceutical inventions were produced either in the course of daily 
examination of applications, or during special meetings held to discuss and synthesize the committee's jurisprudence. In the latter case, the rules were codified in the form of guidelines or principles, to aid and orientate the rapporteurs' future decisions.

This work of production of rules is explained by the uncertain nature of the law and jurisprudence relative to pharmaceutical process patents in France. The committee worked to define new balances between industry's needs, that is, encouraging chemical and pharmaceutical invention in the aftermath of the war, and public health interests, which prohibited any monopolization of drugs. The creation of this corpus of rules was also justified by the incompleteness of the law which precluded an understanding of particular objects or technical and industrial changes without considerable efforts at interpreting and applying the law and at translating between science, law and industry ${ }^{24}$. The special technical rapporteurs were appointed precisely for that purpose, for example, to decide whether the process of extraction of thyroxin could be considered as a process that was sufficiently defined to warrant a patent, or to rule on the patentability of hormone preparations which had no defined chemical formulae. It was use of the law that defined the norm, that shifted the nature of rulings and that 'invented' pharmaceutical process patents even though the law had not changed. The creation of these guidelines attests to this patient legal work.

In March 1921 the CTPI formalized its guidelines for the first time. The two rapporteurs appointed, one a senior member of the faculty of pharmacy in Paris, the other a lawyer specialized in industrial property, agreed first to separate product patents - which were to be refused - from process patents - which were to be accepted - and, second, to specify the conditions of acceptance of process patents in such a way as to prevent any devious appropriation of the product via appropriation of the process: 'we specified the rules governing application of Paragraph 1, Article 3 of the 5 July 1843 law. The principle identified in this examination is that pharmaceutical product preparation or manufacturing processes are 
patentable even though these products are not, but if that patentability is to be recognized one condition needs to be fulfilled: the process has to be distinct from the product. In other words, a product closely linked to the individuality of the process would indirectly be patented at the same time as the process'. Adjusting the Committee's policy proved to be particularly tricky. Although the idea was for the jurisprudence to evolve so that pharmaceutical process patents could be granted, and invention and industrial research stimulated, it was also necessary to comply with the principle of the 1844 law, that is, the prohibition of any form of monopoly on drugs.

The committee diffused these rules among IP professionals and pharmaceutical firms. Even though the publication of its reports was refused, in order not to substantiate the idea of a prior examination of pharmaceutical patents, the principle of publication of the evaluation rules was retained: 'it would nevertheless be desirable for the new directives adopted by the committee to be known, especially as regards pharmaceutical products, for example' (CTPI, 1922).

The patent engineering profession's representation on the Committee was also relied on for the dissemination of rules: 'Mr Harlé would like to thank the Director for his authorization to discuss this question with his engineer-consultant colleagues' (CTPI, 1925). In 1938 the subject of the dissemination of the Committee's rules among engineer-consultants arose again. It was agreed to publish 'a memorandum highlighting the general conclusions of reports approved by the technical committee ${ }^{25}$, especially to help the patent engineers to limit their claims to manufacturing techniques, without encroaching on pharmaceutical products.

2- The art of defining Patent Scope: between Industrial Motives, the Pharmaceutical Profession and Public Health 
The first rule followed by the CTPI, and the easiest to apply, consisted in eliminating all patent claims that directly concerned medicinal substances, to reduce the scope of a process patent in the strict sense of the term. In 1923 the Committee refused the Mayo Clinic's application for a patent called 'Thyroxin'. Although the rapporteurs agreed that the patent described a real production process, in enough detail to be receivable, they decided to refuse it on the grounds that it covered the substance thyroxin, above all: '... note that the request is simply entitled thyroxin and that it starts with the following terms: "The present invention is relative to a new substance called Thyroxin" ...'. In 1934 the Committee refused a patent by Schering because 'hormones, as remedies or pharmaceutical products, cannot be patented or withdrawn from the public domain'. The rapporteur criticized the scope of this patent which covered not only products derived from a group of hormones but also all the oestrogen components that might have an effect similar to the same class of hormones. Very often the CTPI made the acceptability of a patent contingent on deletion of any reference to the product, both in the claims and in the patent description. Only process patents could be maintained: 'The claim concerns not only general preparation processes but also the compounds obtained by the said processes. We think that the present request cannot be received unless the examples concerning products of a pharmaceutical nature are eliminated from the description' (IG Farben patent, 1928). The committee stipulated that products had to be put into the public domain: 'The summary as it is worded tends towards the granting of a monopoly on the product itself, which is unacceptable' (Deutsche Gold und Silber patent, 1937). Although the applicants generally included this rule in their patent application to avoid a refusal, in January 1938 a member of the committee pointed out that 'regrettable attitudes are still found in many patent applications where there is an automatic switch from process to product. He regrets that patent agents are not familiar with the Committee's rules. Is there no means to inform them of these questions of jurisprudence?'. In the same year a professor of pharmacy even noted an excess in 
Schering's patent: 'Mr Delaby would like to point out that the company Schering is now requesting the patentability of products, contrary to its previous practice ${ }^{26}$.

Second, the CTPI aimed to put into the public domain all claims concerning 'simple mixtures' or drug formulae. The rapporteurs considered that all these 'manipulations' were more a matter of pharmacists' dispensaries than industry, of know-how rather than invention, and should not be cluttering the industrial property scene: 'the addition of adjuvants or excipients is standard practice in the art of pharmaceuticals, without being patented'; 'the way of going about it is not a process' (November 1938). This ruling placed the pharmacist's dispensary beyond the scope of patents: 'the preparation of a particular mixture is not a process; it is above all the perfecting of a formula of administration of a drug, a formula that can be executed in the pharmacist's dispensary'. The committee was concerned about preserving pharmacists' freedom to practise as they wished: '...it would be enough to add some substance to insulin for the patent to be granted. Issuing a patent would prevent the pharmacist from making the mixture, it would prevent manipulations from being done at the counter of the dispensary' (Committee meeting, 22 May 1938). The dispensary's 'mixtures' were different to the 'manufacturing processes' of the synthetic chemicals industry and laboratories: 'It is not a matter of a manufacturing process: these manipulations demand neither the use of special appliances, nor an operational process, nor any chemical reactions or manoeuvres of any laboratory' (patent, 1923). In the case of mixtures it was not possible to separate the process from the product, which for the CTPI was a unacceptable condition: 'we end up not with a chemical body but with a pharmaceutical compound and the manipulations described cannot be likened to a preparation process for a defined product' (patent, 1924).

The committee endeavoured, thirdly, to distinguish between remedies as such, which were not patentable, and their 'vehicle' or carrier, which was ${ }^{27}$. It considered patentability of the medium of medication acceptable when it was distinct from the drug molecule, when that 
molecule could be combined in another way, and when the medium could apply to other molecules. In all these cases the active principle had to remain a free good. In 1921 the committee accepted a patent application submitted by Eli Lilly for a 'process for the preparation of an alkaloid tablet derived from spruce'. The patentability was recognized in so far as this 'new pharmaceutical form is not limited to the alkaloids of the spruce' and the vehicle proposed could apply to other drug molecules. It therefore required the patent to be reworded so that it would 'claim only the process in its general form, since application of the spruce alkaloid was given simply as an example'. The committee had no difficulty separating the 'vehicle' from the remedy when the inventors wanted to patent radioactive preparation processes for which 'the metallic envelopes are clearly distinct from the radioactive substances' (Deutsche Gasluhlicht Aurer patent, 1928) or a medical means of application of the radium. In the latter case the patent concerned 'drug mediums, which are always patentable. Radium can be applied in other ways: there is no de facto monopoly by granting the patent' (Gitmul patent, 1937). The separation between the remedy and its medium was not always easy to establish. In 1928 and 1929 three successive examinations were necessary to decide on the patentability of a patent applied for by the company Norgine on a 'process for preparing an iodine solid alcohol solution'. In 1928 the rapporteurs decided to refuse the patent, which concerned a 'mixture of various elements constituting a remedy'. The firm appealed, arguing that the mixture in question contained an iodine stabilizing agent that was precisely the invention. In 1929 Camille Poulenc, appointed rapporteur, agreed to the patentability of a new pharmaceutical form of iodine. To reach that conclusion he separated the composition into two elements, the active principle, iodine, and the other products which served simply as a medium for it. In so doing he acknowledged the novelty and inventiveness of the patent: 'We are in the presence of an ingenious process that produces a new result' (Camille Poulenc). 
One of the most essential rules adopted by the CTPI was the patentability of pharmaceutical processes on the basis of the 'definition' of the products thus obtained. The rapporteurs' argument was the following: in the presence of a well-defined and well-described product, it is possible to envisage several ways of obtaining the product and thus of achieving the emergence of a de facto monopoly. By contrast, if the product is not defined clearly enough, users will be bound to the process patent: 'The rapporteurs consider, in general, that if the claims concerns a process for which, due to the undefined character of the product to obtain, the same result cannot be obtained in another way, then the patent application must be refused since in that case granting the patent for the process would result in the de facto patentability of the product, contrary to the provisions of Article 3 of the law of 5 July 1844' (14 March 1921). This principle was discussed extensively and was not easy to apply. Certain members of the committee were opposed to this rule, first because it was an internal rule not based on patent law and, second, because 'it is not clear what a defined product is' (Casalonga, jurist, 1938). For others, 'this criterion proved to be fragile and disappointing; the product that science was powerless to define yesterday is defined today ...' (Vaunois, lawyer, 1935).

Until the end of the 1920s the product had to be defined in terms of its chemical formula. The description of these formulae made it possible to imagine several alternative ways of synthesis, so that the risk of monopolization of drugs was excluded: 'Note that these new bodies are defined absolutely and that the indicated ways of doing so, described in the patent, could be replaced by others that may be envisaged' (CTPI, 1921). Hence, an application for a patent on processes to manufacture albumin compounds was refused in 1925 on the grounds of there being 'little information on the composition of the raw materials and even less on that of the products obtained. In these conditions, one has to admit that the final composition of products is dependent on the manipulations performed for the preparation ... one cannot say that with other manipulations one could attain this same composition'. When the products obtained were 
not defined, it was not possible to envisage substitutable processes. The committee sometimes relaxed its criteria for the definition of chemical products: 'we clearly have here a preparation process and the compounds obtained, for want of a precise chemical formula resembling defined products'. Confronted by members of the committee who were concerned about the absence of a chemical formula or an indication of the fusion point of the product, the rapporteur retorted that the products obtained 'may not be scientifically defined, but since in practice crystals are obtained, they can always be prepared identically, and since the Committee has never demanded either a formula nor a fusion point, it is of the opinion that it can issue the patent, with a note in the report that the products "seem to be defined" ${ }^{28}$. In the absence of a chemical definition, the rapporteur used a pragmatic justification: the products obtained could be reproduced identically.

Another rule based on pragmatism was the committee's wish to make acceptance of patents contingent on the existence of or possibility of conceiving of processes which could be substituted for the one under consideration. In March 1935 the committee had refused a Schering patent on 'processes for preparing alcohols from sex hormones', 'because the process described seemed to be the only one which, to their knowledge, allowed alcohols to be obtained, so that granting a patent would have amounted to granting a de facto monopoly on a therapeutic product'. In 1936 it went back on its decision after Schering's IP adviser informed it of the existence of another process. Application of this principle, that is, the knowledge or imagination of a substitutable process, became singularly difficult for new production processes of new products. If the committee refused the patent, it exposed the first generation of inventors to spoliation by the second generation; if it granted the patent, it allowed a de facto monopoly until the invention of a new process. This dilemma was discussed within the committee. Some rapporteurs wanted to encourage the first inventors; others were resolutely opposed to any risk of a monopoly. 
The committee's jurisprudence was strongly marked by the chemical definition of medicinal substances and by the industrialization of pharmaceutical products based on chemical synthesis. Its rules contrasted 'real manufacturing processes' of the pharmaceutical and chemical industry, with the 'simple mixtures' of pharmacies. Patents were the instrument of a policy of industrialization of pharmaceuticals, which allowed room for the practices of pharmacies ${ }^{29}$. To this initial split between the pharmaceutical industry and the pharmacy was added another, between patentable synthetic chemical products and biological or 'living' products whose chemical composition was not known. The latter were placed beyond the scope of patents, at least before the rules changed in the late 1920 s.

\section{3- Exclusion of Biological Products in the 1920s and Change of the Norm with a Hormone Patent in 1929}

We have seen that when Albert Calmette in 1923 was requested by the University of Toronto to patent insulin in France, he answered that ' ... the preparation of drugs, serums, vaccines and biological products intended for medical use is absolutely free in our country where no patent can protect it'. Although the CTPI gradually developed rules more favourable to the issuing of pharmaceutical process patents, it formally excluded preparations of biological products, especially manufacturing methods for vaccines and serums, at least until the late 1920s. The rules were set from March 1921 in the committee's first guidelines drawn up by Detoeuf, a head of practical studies at the faculty of pharmacy in Paris: 'In line with the theory suggested by Detoeuf, the committee has agreed to distinguish between processes for the preparation of defined products, and processes for the preparation of products without a clearly determined formula, especially living products, serums and vaccines. For the latter, the nature of the product remains linked to the process that spawned it, like the child to its parents, and 
the slightest change in the process would alter the nature of the product; this process is therefore not patentable, for if it were, the product would also be so, indirectly'.

The non-patentability of processes for the preparation of biological products and 'live products' was justified on the basis of three main arguments.

First, patents were refused due to the inadequate definition of the product, which prevented a different process from being designed to obtain an identical product. For the technical committee, biological products - substances extracted from the human or animal body such as hormones or blood, or vaccines and serums produced in a laboratory - were 'essentially undetermined compounds' (report on patent relative to a preparation from the marrow of slaughtered animals, 1926). The rapporteurs noted that they had not been defined and described by a chemical formula; for instance, as regards a measles vaccine, the rapporteur noted that 'even if in the case in point it concerns a process for the preparation of a vaccine, one has to admit that the recommended process does not allow a defined chemical product to be obtained' (Gerutert \& Cie. Patent, 1924). For this patent, the discussion of the technical committee and especially the contribution of Gabriel Bertrand, biologist from the Pasteur Institute, introduced a difference between vaccines, that is, 'living bodies', and serums, 'an ill-defined and purely pharmaceutical substance ${ }^{30}$. In other words, live vaccines, which could be cultivated to produce pure cultures, were entities that were better defined than serums. The committee drew no immediate conclusion and rejected the patent application. The rapporteurs had a model of the chemical product defined by a formula, even if they sometimes took liberties with the formulation in order to accept less strict definitions - such as the existence of crystals that could be reproduced identically. The chemical definition of the product enabled the chemist to conceive of other ways to synthesize it; it was a guarantee against the risk of establishing a monopoly on the drug or the vaccine. As for the undetermined nature of 'living products', the committee's approach was constant throughout the twenties and early thirties: 'we cannot 
recognize the patentable character of products which have the nature of a serum' (concerning an anti-syphilitic serum, May 1923). 'We realize immediately that this product has an undetermined chemical composition' (opinion on a patent relative to a bacterium culture, 1929); 'the serum thus obtained cannot be considered as a defined product' (process for manufacturing a serum against the after-effects of burns, 1934).

Second, the lack of stability and homogeneity of biological products ran counter to the principle of reproducibility of the invention. The variability of life forms was an obstacle often discussed in connection with the extension of industrial property to living organisms and their components $^{31}$. In 1925 the committee refused a patent on a swab for treating wounds, which incorporated 'a serum produced from fresh human or animal blood'. Its argument was that 'since the main element of the product is a live liquid, the therapeutic results will vary depending on the blood used'. In the same year the committee refused a patent on a manufacturing process for 'medicinal milks'. The invention consisted of 'using the bodies of milk-producing animals as agents of transformation, and then recovering the medicinal substances that would have become assimilable ... for that purpose the animal is given set doses of the drug in question and then the active substances are isolated in its milk'. The committee rejected this application due to the variability of the product thus obtained: 'one cannot agree to the existence of a veritable medicinal preparation process since this process could be considered only in the way offeeding the animal. Even by feeding the animal in identical conditions, it has not been proved that one would obtain an identical composition of the assimilable product'. Regarding a product 'derived from animal substances - elements constituting the human umbilical cord or the pig's umbilical cord', the committee concluded that it 'does not have a determined and set composition' (patent, 1931).

Third, 'live products' such as vaccines are altered during the production process. Culture and attenuation methods create a 'modified' living product which is the expression of the 
process. Consequently, it is not possible to dissociate these products from the process through which they are obtained. The CTPI compared this to separating 'children from their parents'. In 1929 it refused a process for preparing animal vaccines' that used aniline colours to attenuate germs: 'one cannot grant a patent for a product as undetermined as a vaccine, since the vaccine preparation process is closely linked to its composition'. It is therefore not possible to conceive of a substitute process. In 1921 the committee had refused a patent on a 'preparation process for non-toxic vaccines' for this reason: 'the elimination of toxic principles achieved by the process described cannot be obtained identically by another process. Consequently the mode of operation leading up to the preparation of a special vaccine cannot be reproduced in other ways'.

By contrast, the recovery of a 'specific microbial antibody against infectious diseases' in patients' secretions is patentable because 'this ferment has undergone no alteration by way of manipulations implemented by the inventor's process ... the inventor takes it in this milieu, isolates it through a series of operations described by him, and delivers it as it was before the preparation, without any modification' ${ }^{32}$. An 'isolated' biological product could be patented, but not a living product 'modified' during a preparation. The live, domesticated, attenuated, altered product depended on the preparation process.

The CTPI also accepted the patentability of vaccine preparation processes provided that the patents did not apply to specific vaccines. In 1923 a 'process patent for the culture of microbes, their heat treatment and the production of microbial vaccines' was accepted, provided that 'the aim of the description was not a particular preparation process of one or several vaccines ... the application was not intended for vaccines but for a process and especially an apparatus that could be used for that purpose'. The patent was granted on condition that the process was sufficiently generic to be able to be applied to a variety of vaccine applications: 'the process applies to any type of vaccine. It is not intended for the patentability 
of a vaccine itself' (vaccine conservation process (1930)). In this type of technical configuration the risk of monopolisation of a determined vaccine is weak. In 1925 the technical committee agreed to a 'vaccinal virus purification process' for the same reason. It noted the existence of several methods for preparing this virus: 'we find ourselves in the presence of a product of a therapeutic nature but one that presents several different modes of preparation'. Acceptance of this patent was also justified by the fact that it concerned a simple virus purification process which did not change its nature. Yet this jurisprudence, more favourable to certain methods for the preparation of vaccines or serums, and occasionally justified by the absence of risk of monopolization of products, did not apply to all similar patent applications. For example, in 1934 all the vaccinal applications of a sterilization process were refused: 'the application to the treatment of various bacilli to attenuate the virulence' is not patentable: 'the culture of microbes for the preparation of remedies could be the object of a patent restricted to the process only if there is no relation between the process and the product' (technical committee, 26 March 1934). In 1937 the committee highlighted the undetermined nature of certain vaccines to exclude a patent on a method of preparing vaccines for humans and animals, that could be applied to many vaccinal preparations: 'The process was claimed for the production of all vaccines. But many of these are still inadequately defined. This is sufficient reason to refuse the patent application.'

These rules for examining biological product preparation processes, based on the absence of a chemical definition of the product, the lack of stability and homogeneity of living products, and the product's dependence on the preparation process are not always easily applied. We have seen the differentiation introduced by Gabriel Bertrand in 1924, between the vaccine, a 'living body', and the serum, 'an undefined substance'. A distinction was also made between processes for obtaining modified living products, whose patentability was not accepted, and processes for preparing living products or their isolated and purified elements, 
which could be patented when the inventor did not alter the living body ${ }^{33}$. This principle of indeterminacy of biological products clashed with cases in which the inventor provided the chemical formula of complete or semi-complete extracted natural substances, or even proposed their synthesis. A noteworthy patent application from this point of view was submitted to the CTPI in 1923, concerning thyroxin isolated by Kendall and patented by the Mayo Clinic ${ }^{34}$. The committee acknowledged that the patent contained an isolation process described in detail, and that this produced 'a clearly defined process characterized by its fusion point, its chemical characteristics, its formula ...'. Finally, it noted that 'the product can be reproduced synthetically'. The criteria of acceptance of the manufacturing process were satisfied: the process was perfectly described and 'one can conceive of the elaboration of another process leading up to the same product since the latter is a chemical entity whose characteristics are rigorously specified' ${ }^{35}$. In spite of this, the committee refused the patent on the grounds that the substance was defined as the heart of the invention.

This rule, highly unfavourable to biological products, changed in 1929 on the basis of a singular patent application filed in May 1928 by the company Organon, on 'a process for separating active ovarian hormones'. The first examination in January 1929 concluded with refusal of the application. The rapporteurs were opposed to the claim concerning the product, and the applicant agreed to delete reference to it. The committee then rejected the process claim since it 'leads to a body with an essentially undetermined composition for which no characteristic is indicated since the process cannot be separated from the product itself'. A second examination was carried out in May 1929 following a protest by Organon which refused the argument that the hormone composition was 'undetermined'. A direct discussion was organized between the inventor of the process and one of the rapporteurs. The inventor gave the committee documentation, along with a technical report on recent scientific work. In their second examination the two rapporteurs, a pharmacist and a jurist (as specified in the 
regulations), modified their position and agreed that 'ovarian hormones are bodies which cannot currently be identified perfectly'. The most important change concerned criteria for the definition of pharmaceutical products. While the rapporteurs noted that 'we know nothing of the chemical composition of ovarian hormones and their physical constants are very imperfectly determined', they introduced a new criterion for the definition of products: 'but some of their biological reactions make it easy to characterize them'. This decision led to a considerable broadening of the definition of 'defined products', evident in the committee's collective discussion on this patent: 'the term defined product must not be taken only in its chemical sense. Products can be defined biologically, without having a formula and precise constants'. Or, 'the notion of a defined product is somewhat tight; the product would have to be identifiable by some means and not only by a formula'.

To justify acceptance of this patent, the technical committee mobilized several arguments stemming from the advancement of research on this product category, and from the patent economy.

First, it took into account the growth of research on hormones to trust the inventor with future progress in the chemical definition of these entities: 'the state of advancement of scientific studies on hormones is such that these are likely to be characterized fairly shortly'.

Second, it wished not to penalize the first inventor to the advantage of the following inventors who would have more evidence for defining the product: 'if we refused the present application, we would penalize the current inventor to the advantage of subsequent inventors'.

Third, it referred to the patenting of several other biological products, especially pepsin, which had no chemical definition but could be measured perfectly, or adrenalin, which could be synthesized ${ }^{36}$. Progress in science led to the integration of biological products in the field of chemistry. 
Fourth, the committee could grant this patent without any risk of monopolisation of these products since several other processes for preparing hormones already existed.

Fifth, patents had already been granted abroad for the process in question.

Several months later a jurist on the technical committee noted the shift in the rules: 'the technical committee's recent decision in the hormone affair seems to have oriented the committee's jurisprudence in a slightly new direction'.

This change was finally confirmed in new guidelines drawn up in 1935-1936. Professor Delaby's memorandum on 'the extension of the granting of patents to products defined by precise biological characteristics', published for firms and IP consultants, was an attempt to define criteria of acceptability and refusal for three product categories. Hormone-based drugs, including 'mixtures of active species', which satisfied biological tests expressed in rat units, mouse units and rabbit units ${ }^{37}$, were patentable. Cardio-tonic drugs which had satisfied physiological essays were also acceptable. For vaccines, Delaby distinguished between 'identifiable products' containing known toxins or living bacilli, which could be cultivated and were therefore 'easily identifiable' and patentable, from 'killed vaccines' which 'incorporated widely diverse unidentifiable products' that did not qualify for patents. Apart from the fact that they opened the range of patentable pharmaceutical inventions, these new guidelines considerably altered the qualification of receivable products. The criteria of acceptability were no longer only the chemical definition of the molecule nor even its purification. Measurements of the physiological effect of products on the organism counted just as much. Patents for imperfectly purified extracts had become acceptable where tests had shown their effects on the organism $^{38}$. In 1938 a patent on the preparation of a malaria drug was granted. It was of course the mixtures that were patented but, above all, the pure species contained in these mixtures were identified and 'chemo-therapeutic signs are sufficient for characterizing them biologically'. Patents on preparations of hormone-based substances, formerly refused, were accepted: '... 
since the technical committee decided to propose granting a patent on a process for manufacturing substances defined by precise physiological essays, and the applicants indicated sufficient data for the biological definition of the product in question, the rapporteurs think that the patent can now be issued'. In the case of a patent granted in 1937: 'the biological property of reducing the blood pressure and some other indicated physical characteristics suffices for the determination of this hormone in the current state of affairs'.

\section{Conclusion}

The work of the Comité Technique de la Propriété Industrielle during the inter-war period illustrates the making of patent law by an organization consisting of scientific, legal and industrial experts. Whereas the legal norm relative to drug patents remained unchanged, the practice of examining applications for 'patents that seemed to concern remedies' resulted in the granting of patents on an increasing number of pharmaceutical processes covering an everwider range of health products. The technical committee produced its own corpus of examination rules - both during the practice of evaluating patent applications and during special sessions devoted to drawing up guidelines - which was superimposed over the legal norm. The committee codified and transmitted this body of rules accumulated over a twenty-year period so that new rapporteurs could refer to it. It also disseminated it among patent applicants or patent engineers, either via publication in a journal of the Office National de la Propriété Industrielle, or via IP consultants on the committee, or else during direct interaction with patent engineers around contentious cases. The rules changed during that period. Singular patents such as the one requested by Organon in 1929 changed the law in so far as discussions introduced new criteria for the definition of drug products and acceptability of pharmaceutical patents. Firms also participated in the production of patent law, for instance Organon in 1929 and 
Schering in 1935, which fiercely defended their claims on processes for preparing biological products $^{39}$. Finally, it was use of the law, by firms, examiners and experts from the technical committee at the patent office, that transformed pharmaceutical patent norms in the period between the two World Wars.

One of the most noteworthy changes introduced by the CTPI concerned the status of biological product preparations. In 1936 Professor Delaby's memorandum relative to 'the extension of the granting of patents on products defined by precise biological characteristics' codified this shift. Until then the rapporteurs of the committee almost systematically refused processes for preparing serums and vaccines, and substances extracted from the bodies of humans or animals. These refusals were justified on the grounds of an insufficient purity and chemical definition of products, a lack of homogeneity and stability of living products, and the impossibility of separating the product from its preparation process when the living organism was modified by that process. For the examiners, ignorance of the chemical formula of the product was unacceptable: it precluded any other way of obtaining the product and thus led to monopoly. The debate on Organon's patent applications in 1929 and then on those filed by Schering in the early 1930 s for hormone preparations shifted the rules. First, the committee acknowledged the effort at chemical characterization of hormones and the promise of a future synthesis of these products. It then agreed to take into account biological measurements of these products' activity. It was the physiological effect of the product that made it possible to define it, even though its chemical definition was not yet deciphered. This was the case of insulin ${ }^{40}$ and many hormonal preparations. The standardization of biological products on the basis of the measurement of their physiological effects, in 'rat units' or 'rabbit units', made it possible to bypass the limits of their purification or their chemical definition. By taking their physiological and clinical effects as a criterion of pharmaceutical products, the CTPI changed the definition of drugs: they were defined no longer by their chemical nature but by their biological effects. 
It was thus biology and clinical medicine that determined the patentable. To consider the patentability of vaccines, the technical committee envisaged another approach to definition, that of pure culture in the laboratory, which allowed for 'defined products' to be obtained. In his 1936 memorandum, Delaby contrasted 'living vaccines' that could be determined by lab cultures, with 'killed vaccines' whose composition remained undetermined. In so doing the committee incorporated into its judgement criteria the domestication of micro-organisms in the laboratory and the pure culture method developed in the 1860s by Pasteur. In 1937 'bacteriologists agreed that one cannot control the nature of the measles virus after culture'. Another noteworthy fact in the CTPI's rules relative to biological preparations was the absence of considerations on the patentability of 'products of nature' or things that were discovered ${ }^{41}$. Better still, the technical committee justified the patentability of processes for isolating biological substances when living products had not been modified by the operation. In other words, obtaining a living product that was simply isolated was acceptable, whereas a process of attenuation of a micro-organism in the laboratory, 'domesticated', less close to 'nature', was refused. The patentability of 'living products' was questioned from the angle of problems of purification, description and reproduction of the object obtained, and not from that of the preexistence of the patented thing.

Although the practice of appropriation of pharmaceutical inventions progressed in France between the wars, we cannot say that the prevailing IP regime was very strong at that stage. First, laboratories gave up filing patent applications in France, where they thought there was an absolute exclusion of pharmaceutical inventions, both processes and products. The most remarkable case concerns the production of insulin, for which the Pasteur Institute, acting for Toronto University, believed that no protection was possible in France. Second, even though the CTPI accepted process patents, it systematically refused processes for the preparation of biological products, especially vaccines and serums, which were therefore freely copiable, at 
least until the mid-1930s. Third, the same committee was careful to refuse all pharmaceutical product patents, which remained in the public domain, even though a production process concerning them would be patented. In so far as process patents have a narrower spectrum of protection than product patents, copying drugs was allowed provided that the initial process was altered. Fourth, the committee also tended to refuse patents on drug formulae or simple mixtures which were not considered as 'real production processes'. In so doing, it intended to place pharmaceuticals outside the range of patents. All these limits to the attribution of pharmaceutical patents increased the public domain and the space of free copying to an equal degree. French laboratories, including the leading ones such as Rhône Poulenc, had a policy of systematic copying of foreign inventions; they took pharmaceutical patents issued in France and abroad and copied them in their laboratories ${ }^{42}$. This practice of reproduction of inventions was not antinomic with innovation. It was even a way for process innovation and sometimes the discovery of new drugs such as those of the therapeutic properties of white sulphonamide at the Pasteur Institute in 1935-36. Chemists and physiologists of the therapeutic chemistry laboratory thus started to reproduce manipulations and the product described in the German patent, published in France prior to its publication in Germany, before they made their discovery on the raw material of red sulphonamide. Moreover, Rhône Poulenc applied for three patents on preparation processes for products derived from benzène sulfamide ${ }^{43}$. In France the property regime of pharmaceutical invention, which placed products in the public domain and accepted process patents, authorized an innovation regime that combined copying, invention and limited protection. It was exactly the model that was wished for from 1915 to stimulate progress in the French chemicals industry (no product patents, only process patents). This property regime was effectively used by a number of French laboratories which developed their R\&D capacities, such as Rhône Poulenc, the Pasteur Institute's therapeutic chemistry laboratory, and the Laboratoires Français de Chimiothérapie for hormone preparations. Further investigations are 
needed to define the use that was then made of patents by these French pharmaceutical laboratories, for the purposes of copying as well as protection ${ }^{44}$.

\section{Notes}

\footnotetext{
${ }^{1}$ Cassier, "Genome Patents Nowadays and Pharmaceutical Patents in the 19th: a parallel", 22 pages.

${ }^{2}$ Pouillet, Traité théorique et pratique des brevets d'invention, 1872 ; Mainié, Nouveau traité des Brevets d'Invention, 1896 ; Sénac, De la brevetabilité du produit pharmaceutique. Etudes de Législation comparée, 1943.
}

${ }^{3}$ This superiority is clearly legible in the lists of chemical patents issued to German firms by the French Patent Office before the 1914 war: Archives of the Institut National de la Propriété Industrielle, Paris.

${ }^{4}$ Guérin, Les brevets d'invention dans l'industrie chimique, 1922. M. Plaisant, Deuxième rapport sur les brevets d'invention (annexe au PV de la séance du Sénat du 14 février 1933); De Haas, Brevets et médicaments en droit français et en droit européen; Petranker, Droit français et droit allemand en matière de brevets concernant la protection de différentes inventions dans le domaine de la chimie, tome 148 .

5 Plaisant, Le projet de loi sur les brevets d'invention de 1925 à 1933, and the debates of the Office des Brevets between 1915 and 1933, archives of the INPI.

${ }^{6} \mathrm{Cf}$. the curves of pharmaceutical patents examined and authorized by the CTPI between 1920 and 1939.

${ }^{7}$ Law N ${ }^{\circ} 21$ of 27 January 1944, an amendment to the law of 5 July 1844 on invention patents.

${ }^{8}$ Fourneau, "La fabrication des produits pharmaceutiques assurée par l'industrie française", May-June 1915..

${ }^{9}$ Camille Poulenc was the founder of Etablissements Poulenc.

${ }^{10}$ Comité Technique de la Propriété Industrielle, June 1935.

${ }^{11}$ Cassier,. Sinding, 'Patenting for the Public Interest': Administration of Insulin Patents by the University of Toronto".

${ }^{12}$ Letter to the insulin committee, Albert Calmette, 24 Octobre 1923, University of Toronto Archives, A1982-2001, Box 62, Folder 1.

${ }^{13}$ Letter to the insulin committee, Albert Calmette, 24 Octobre 1923, op. citée.

${ }^{14}$ Report to the Insulin Committee on F. Lorne Hutchinson's mission to Europe in the summer of 1924, Toronto, 14 January 1925.

${ }^{15}$ A bill to reform the patent law was passed by the Chamber in April 1927, but it was finally cancelled. It provided for the establishment of general regulations on process patents in the chemicals and pharmaceutical industry, by recognizing pharmaceutical process patents and prohibiting chemical 
product patents. M. Plaisant, 1933, op. cit.

${ }^{16}$ Galvez-Behar,"Des brevets à l'examen. Le rôle du Comité Consultatif des arts et manufactures dans la prise de brevets au début du $20^{\text {ème }}$ siècle ", 11 pages.

${ }^{17}$ Speech by the Minister of Trade, CTPI session on 25 March 1920.

${ }^{18}$ Speech by the Minister of Trade, 15 March 1920, op.cit.

19 Plaisant, 1933, Le projet de loi sur les brevets d'invention de 1925 à 1933, op.cit.

${ }^{20}$ CTPI meeting of june 1926.

${ }^{21}$ CTPI, june 1926.

${ }^{22} 25$ June 1923 sitting, INPI archives.

${ }^{23}$ The Rigollot patent for a preparation of mustard was cancelled in 1872 by the Lyon appeal court which considered that this product was already in the public domain, Sénac, 1943, op. cit.

${ }^{24}$ This work of translation is described for the production of patents on monoclonal antibodies, by Cambrosio and Keating: 'Technique, outil, invention : les transformations d'une biotechnologie', 349364.

${ }^{25}$ CTPI, January 1938.

${ }^{26}$ In 1938 and 1939 the company Schering alone had over 20\% of the pharmaceutical patents examined by the CTPI, that is, 27 out of 127 .

${ }^{27}$ Pouillet, op.cit.; Mainié, op. cit.; Sénac, op. cit.

${ }^{28}$ CTPI, 28 January 1929.

${ }^{29}$ Patentability was justified by the industrialization of modes of pharmaceutical production and progress in the definition of products: 'the prohibition on patenting pharmaceutical compounds which may have been logical and necessary when the 1844 law was passed, at a time when most remedies still consisted of more or less imaginative mixtures of substances, is hardly justified today with the advancement of pharmaceutical science'. Patents were to reward and stimulate the new pharmaceutical industry based on chemistry, while pharmacy preparations remained non-patentable: 'it seems necessary to make a distinction and to allow patentability, not for pharmaceutical compounds but only for defined chemical products, even for a purely pharmaceutical use', 'Rapport complémentaire sur la modification de la loi sur les brevets d'invention', CTPI, 26 April 1920.

${ }^{30}$ CTPI, 1924.

${ }^{31}$ Beier, Crespi and Straus, Biotechnology and patent protection, an international review.

${ }^{32}$ Report of 28 November 1921.

${ }^{33}$ Surprisingly, these rules differ from current controversies on the patentability of life forms: whereas some people are in favour of patenting modified living organisms, they refuse that of organisms which have simply been 'isolated' from their natural environment. See, for instance, the 'Opinion on the ethical aspects of patenting inventions involving human stem cells', The European Group on Ethics in Science and New Technologies to the European Commission', 7 May 2002. 
34 ' Rasmussen, Developing the Hormones of the Adrenal Cortex', 40 pages.

${ }^{35}$ Concerning the extraction of active principles of plant biological origin, the committee accepted processes when 'it is sure that these medicinal principles have a clearly defined chemical formula that is enough to give the products themselves the character of defined chemical products' (patent for the extraction of active biological principles of the male fern).

${ }^{36}$ Adrenalin was patented in 1900 and these patents were attacked on the grounds of the pureness of the product obtained: Simon, 'Adrenalin, Epinephrin ou Suprarenin? Identifying the true hypertensive principle', 11 pages.

${ }^{37}$ These biological measurements were used in the standardization of vaccines and of insulin between the two World Wars. See C. Sinding's work on the standardization of insulin, Bulletin of the History of Medicine, 2002.

${ }^{38}$ Delaby notes that 'this set will sometimes have a greater activity than any one of its principles subsequently isolated'. The purification of the product becomes secondary compared to its physiological and clinical effect.

${ }^{39}$ More recently, Daniel Kevles highlighted the role of General Electric jurists in the transformation of patent law on life forms during a lawsuit concerning the Chakrabarty bacterium: 'A History of Patenting Life in the United States With Comparative Attention to Europe and Canada'.

40 Sinding «_Making the unit of insulin : standards, clinical work and industry », 231-270.

${ }^{41}$ This question was raised during the examination of the adrenalin patent at the beginning of the century (Simon, op.cit.). In France, in 1922, the Appeal Court of Paris refused a patent on a mushroom because, even though it was isolated for the first time by the applicant, and was of interest to the agrifood industry, it was not a new industrial product but simply the discovery of a useful natural product. In 1943 the San Francisco Federal Court of Appeals invalidated Steenbock's patents on vitamin D and the irradiation of foods with ultraviolet rays, on the grounds of it being a natural process that had not been invented by man: Apple, 'Patenting University Research. Harry Steenbock and the Wisconsin Alumni Research Foundation'. The weight of the doctrine of 'products of nature' in the first half of the 20th century is clearly described in Beier, Crespi and Straus "Biotechnology and patent protection, an international review".

${ }^{42}$ See the account by Bovet, Une chimie qui guérit.

${ }^{43}$ White sulphonamide itself could not be patented in so far as it had been published at the beginning of the century. Moreover, in France it was not possible to directly patent a product.

${ }^{44}$ This practice of copying by French laboratories is described by Chauveau in L'invention pharmaceutique, 152-160; and by Baverey: 'De la copie au nouveau médicament', 48-63. At the same time, the extension of patentability to include pharmaceutical processes was justified by the need to protect new research laboratories: 'since 1844 the art of healing and pharmaceuticals have undergone profound change. In France there is a large pharmaceutical industry based on the committee's jurisprudence. This industry has invested huge sums in building and maintaining research laboratories; the application of stricter principles would put it in a difficult position' (Delaby, CTPI, 1936).

\section{References}

Apple, Rima, 'Patenting University Research. Harry Steenbock and the Wisconsin Alumni Research Foundation', Isis, 80, (1989) 375-394 
Baverey, Séverine: 'De la copie au nouveau médicament', Entreprises et Histoire, 36, (2004) $48-63$

Beier, Friedrich Karl, Crespi R. Stephen, and Straus, Joseph, Biotechnology and patent protection, an international review, OECD, 1989.

Bovet, Daniel, Une chimie qui guérit, Payot, 1989

Cambrosio Alberto and Keating, Peter : 'Technique, outil, invention : les transformations d'une biotechnologie', Sociologie du Travail 3 (1996) 349-364

Cassier, Maurice, "Genome Patents Nowadays and Pharmaceutical Patents in the 19th: a parallel", International Conference, "Technological Policy and Innovation: Economic and historical perspectives", Paris, 20-22 November 2000, 1-22

Chauveau, Sophie, L'invention pharmaceutique, Les Empêcheurs de penser en rond, 1999.

De Haas, Michel, Brevets et médicaments en droit français et en droit européen, Paris Litec, 1981

Fourneau, Ernest, 'La fabrication des produits pharmaceutiques assurée par l'industrie française", Bulletin de la Société d'Encouragement pour l'Industrie Nationale, (1915) 444475.

Galvez-Behar, Gabriel "Des brevets à l'examen. Le rôle du Comité Consultatif des arts et manufactures dans la prise de brevets au début du $20^{\text {ème }}$ siècle ", Université Lille 3, 1-11

Guérin, Maurice, Les brevets d'invention dans l'industrie chimique, Paris Dalloz, 1922

Kevles Daniel, 'A History of Patenting Life in the United States With Comparative Attention to Europe and Canada', a report to the European Group on Ethics, 2002.

Mainié, Fernand, Nouveau traité des Brevets d'Invention, Chevalier Marescq et Cire, Paris, 1896.

Petranker, Léon, Droit français et droit allemand en matière de brevets concernant la protection de différentes inventions dans le domaine de la chimie, tome 148, LGDG, Montchrétien, 1976.

Plaisant, Marcel, Le projet de loi sur les brevets d'invention de 1925 à 1933, Paris, Imprimerie Desfossés, 1933.

Pouillet, Emile, Traité théorique et pratique des brevets d'invention, Paris, Marchal, Billard et Cie, 1872 
Rasmussen Nicolas, 'Developing the Hormones of the Adrenal Cortex', N., Max Planck Institute for the History of Science, Berlin, 2002, 1-40.

Sénac, Daniel, De la brevetabilité du produit pharmaceutique. Etudes de Législation comparée, Paris, Editions Montchrestien, 1943.

Simon, Jonathan, 'Adrenalin, Epinephrin ou Suprarenin? Identifying the true hypertensive principle', Max Planck Institute for the History of Science, Berlin, 2002, 1-11

Sinding Christiane, "Making the unit of insulin : standards, clinical work and industry », Bulletin of the History of Medicine, 76 (2002) p 231-270. 